Helen W. Karl MD, Donald C. Tyler MD, Elliot J. Krane MD

\section{Respiratory depression after low-dose caudal morphine}

Objectif: Présenter un cas de dépression respiratoire consécutive à l'injection caudale d'une petite dose de morphine.

Éléments cliniques: Un jeune garçon âgé de 15 mois était opéré pour une réimplantation urétérale sous anesthésie générale endotrachéale combinée à de la bupivacaïne 0,25\% $10 \mathrm{ml}\left(2,5 \mathrm{mg} \cdot \mathrm{kg}^{-1}\right)$. Quatre-vingt-dix minutes après la bupivacaïne, de la morphine $0,4 \mathrm{mg}\left(1 \mathrm{mg} \cdot \mathrm{ml}^{-1}, 0,4 \mathrm{ml}, 0,04\right.$ $m g \cdot \mathrm{kg}^{-1}$ ) était injectée après un test d'aspiration négatif. Un peu plus de deux heures après l'administration caudale de morphine, le patient devenait léthargique et sa saturation en oxygène diminuait (à $62 \%$ ) sans que sa fréquence cardiaque et respiratoire n'ait changé. L'injection intraveineuse de nalo. xone $0,1 \mathrm{mg}\left(0,01 \mathrm{mg} \cdot \mathrm{kg}^{-1}\right)$ améliorait considérablement son niveau de conscience. De l'épinéphrine racémique était aussi administrée pour traiter un stridor surajouté. Le patient a eu besoin d'une perfusion continue de naloxone $(0,001-0,002$ $\left.\mathrm{mg} \cdot \mathrm{kg}^{-1} \cdot \mathrm{h}^{-1}\right)$ pendant 12 heures à l'unité des soins intensifs. Il était libéré deux jours après l'opération sans autres complications.

Conclusion: Une dépression respiratoire peut survenir chez des enfants de plus d'un an, même lorsque les doses de morphine administrées sont minimes. La baisse de la saturation en oxygène et la léthargie constituent des signes importants. Le maintien d'une fréquence respiratoire normale malgré une hypoxémie importante plaide en faveur de l'oxymétrie de pouls (à l'air ambiant lorsque c'est possible) comme moniteur électronique préfêrablement à la pneumographie par impédance.

Clinically important, delayed, respiratory depression in paediatric patients after neuraxial opioids ${ }^{1-3}$ has been described only with concomitant systemic opioids and/or epidural morphine doses $>0.05 \mathrm{mg} \cdot \mathrm{kg}^{-1}$, ${ }^{1,2}$ or in infants <eight months. ${ }^{2}$ We report a case of respiratory depression after a small dose of caudal morphine administered to a 15-mo-old child.

\section{Case report}

A $15 \mathrm{mo}, 9.8 \mathrm{~kg}$ boy was scheduled for ureteral reimplantation. He had had an uncomplicated general anaesthetic two weeks previously. The only history of note was that he frequently snored at night.

The patient received no premedication. Anaesthesia 
was induced with thiopentone, and tracheal intubation was facilitated with vecuronium. A $4.0 \mathrm{~mm}$ I.D. endotracheal tube allowed a gas leak $<10 \mathrm{~cm} \mathrm{H}_{2} \mathrm{O}$. It was changed to a $4.5 \mathrm{~mm}$ I.D. tube which allowed no gas leak; therefore the $4.0 \mathrm{~mm}$ endotracheal tube was replaced. An $18 \mathrm{G}$ intravenous catheter (Terumo, Elkton $\mathrm{MD}$ ) was placed in the caudal epidural space. A 20gauge open tip epidural catheter (Burron, Bethlehem PA) was threaded through the intravenous catheter without resistance and taped at $8 \mathrm{~cm}$. Aspiration was negative, and a test dose of $1 \mathrm{mi}$ of bupivacaine $0.25 \%$ with $5 \mu \mathrm{g} \cdot \mathrm{ml}^{-1}$ epinephrine did not change heart rate. Surgery was performed under an additional $9 \mathrm{ml}$ of the above solution and halothane (inspired $0.2-0.3 \%$ ) in $\mathrm{N}_{2} \mathrm{O} 70 \%$ and $\mathrm{O}_{2}$. Ninety minutes after the bupivacaine, $0.4 \mathrm{mg}\left(0.04 \mathrm{mg} \cdot \mathrm{kg}^{-1}\right)$ undiluted preservative-free morphine $\left(1 \mathrm{mg} \cdot \mathrm{ml}^{-1}, 0.4 \mathrm{ml}\right)$ was injected after negative aspiration using a $1 \mathrm{ml}$ syringe. The injection was followed by an equal volume of preservative-free saline. The surgical procedure was completed $30 \mathrm{~min}$ later and, after one hour in the post-anaesthesia care unit (PACU), he was transferred to a surgical nursing unit. At that time, the patient was awake, his arterial oxygen saturation by pulse oximetry $\left(\mathrm{SpO}_{2}\right)$ was $97 \%$ while breathing room air and good leg movement had returned. Ward monitoring included a pulse oximeter (alarms: $\mathrm{SpO}_{2}$ $<92 \%$, heart rate $<70$ beats $\cdot \mathrm{min}^{-1}$ ). Oxygen, delivery device with mask, suction and naloxone were available at the bedside.

Forty minutes after transfer ( $2.2 \mathrm{hr}$ after caudal morphine), the patient developed decreases in oxygen saturation as low as $62 \%$ without change in heart rate $(100-142 \mathrm{bpm})$ or respiratory rate $(20-28$ breaths $\cdot \mathrm{min}^{-1}$ ). No analgesics or sedatives other than those listed above had been administered. The patient's heart rate on auscultation correlated with that on the pulse oximeter. He became lethargic and had mild stridor. No other analgesics or sedatives had been administered. Oxygen and chin lift raised the oxygen saturation to $100 \%$. Racemic epinephrine was administered for treatment of suspected subglottic oedema. Naloxone 0.1 $\mathrm{mg}\left(0.01 \mathrm{mg} \cdot \mathrm{kg}^{-1} \mathrm{iv}\right)$ markedly improved his level of consciousness. The patient was transferred to the intensive care unit, an additional $0.05 \mathrm{mg}\left(0.005 \mathrm{mg} \cdot \mathrm{kg}^{-1}\right)$ of naloxone was given $2.5 \mathrm{hr}$ later, followed by $11 \mathrm{hr}$ continuous infusion $\left(0.001-0.002 \mathrm{mg} \cdot \mathrm{kg}^{-1} \cdot \mathrm{hr}^{-1}\right)$. A second nebulized racemic epinephrine treatment was required.

The next morning, the patient returned to the surgical nursing unit and he was discharged home the following day. In addition to the single dose of caudal morphine administered in the operating room, the only analgesics the child required were four doses of ketorolac $i v$ and two doses of oxycodone po with acetaminophen.

\section{Discussion}

This child's clinical course illustrates that respiratory depression can occur in children greater than one year of age, even when small doses of caudal morphine are used.

One question that arises after an unexpected response to medication injected via the epidural route is whether the catheter tip was in the appropriate place. If it had been in the subarachnoid space, one would expect a profound sensory and motor block after $2.5 \mathrm{mg} \cdot \mathrm{kg}^{-1}$ bupivacaine. ${ }^{4}$ This was not observed. A radiographic study using $1 \mathrm{ml}$ of a non-ionic contrast agent such as Omnipaque ${ }^{\circledR}$ could have been used to confirm epidural catheter placement.

This patient's recovery was further complicated by mild laryngeal oedema (more likely after multiple intubations ${ }^{5}$ ) and airway obstruction from pre-existing presumed adenotonsillar hypertrophy. Habitual snoring in the 12-15 month age group is not uncommon: of one group of toddlers (mean age $42.2 \mathrm{mo}$ ) reported to "snore every night," more than half began to snore before their first birthday. ${ }^{6}$ Chronic upper airway obstruction (and perhaps occult sleep apnoea) is a risk factor for postoperative respiratory depression. The potential aggravation of the opioid-induced hypoventilation by pre-existing soft tissue hypertrophy emphasizes the importance of eliciting this history preoperatively.

The choice of patient monitoring after epidural opioids is poorly defined. Some healthy adults are monitored only as part of the nursing protocol. ${ }^{7}$ Because respiratory depression in children who receive epidural opioids without supplemental $i v$ sedation is rare, ${ }^{3}$ some suggest that monitoring with pulse oximetry is unnecessary. This case illustrates the potential danger of not monitoring arterial oxygen saturation: the first sign of respiratory compromise was decreased oxygen saturation, not bradycardia or bradypnea. Clearly, provision must be made for continuous attention to the device's alarm by personnel in an intensive care unit, a central attended nursing station around which patient rooms are arranged as is the case in our hospital, or by telemetry.

Because this child's respiratory depression persisted for many hours, because others have reported the onset of respiratory depression as late as $11.5 \mathrm{hr}$ after caudal morphine administration, ${ }^{2}$ and because $\mathrm{CO}_{2}$ response curves are still depressed by epidural morphine at 22 $\mathrm{hr}^{8}{ }^{8}$ we advocate pulse oximetry for at least $18 \mathrm{hr}$ after a single dose of epidural morphine, as has been recommended for intrathecal morphine. ${ }^{9}$ As long as oxygen saturation is in an acceptable range ( $>92 \%$ ), the patient should be breathing room air in order to avoid obscuring the diagnosis of hypoventilation.

In summary, life-threatening hypoxaemia in a child 
over one year of age after $0.04 \mathrm{mg} \cdot \mathrm{kg}^{-1}$ epidural morphine emphasizes the importance careful monitoring of paediatric patients after epidural opioids. Decreased arterial oxygen saturation and lethargy are important heralds of severe respiratory depression. This child's responsiveness to naloxone indicates that the hypoventilation was primarily opioid-related; however, other factors (mild tracheal oedema in the setting of chronic upper airway obstruction during sleep) may have contributed. A normal respiratory rate despite substantial hypoxaemia argues that pulse oximetry (without supplemental oxygen where possible) has a clear advantage over impedance pneumography for electronic monitoring.

\section{References}

1 Krane EJ. Delayed respiratory depression in a child after caudal epidural morphine. Anesth Analg 1988; 67: 79-82.

2 Valley $R D$, Bailey $A G$. Caudal morphine for postoperative analgesia in infants and children: a report of 138 cases.

Anesth Analg 1991; 72: 120-4.

3 Sang CN, Berde CB, Safety in Pediatric Regional Analgesia Study Group. A multicenter study of safety and risk factors in pediatric regional analgesia. Anesthesiology 1994; 81: A1386.

4 Harnik EV, Hoy GR, Potolicchio S, Stewart DR, Siegelman $R E$. Spinal anesthesia in premature infants recovering from respiratory distress syndrome. Anesthesiology 1986; 64: 95-9.

5 Koka BV, Jeon IS, Andre JM, MacKay I, Smith RM. Postintubation croup in children. Anesth Analg 1977; 56: 501-5.

6 Zucconi M, Ferini Strambi L, Pestalozza G, Tessitore E, Smirne $S$. Habitual snoring and obstructive sleep apnoea syndrome in children: effects of early tonsil surgery. Int J Pediatr Otorhinolaryngol 1993; 26: 235-43.

7 Ready LB, Loper KA, Nessly M, Wild L. Postoperative . epidural morphine is safe on surgical wards. Anesthesiology 1991; 75: 452-6.

8 Attia J, Ecoffey C, Sandouk P, Gross JB, Samii $K$. Epidural morphine in children: pharmacokinetics and $\mathrm{CO}_{2}$ sensitivity. Anesthesiology 1986; 65: 590-4.

9 Nichols DG, Yaster M, Lynn AM, et al. Disposition and respiratory effects of intrathecal morphine in children. Anesthesiology 1993; 79: 733-8. 